\title{
Polimorfisme C1167T Gen Reseptor Tipe II Transforming Growth Factor- $\beta$, Kadar Soluble Endoglin, dan Vascular Cell Adhesion Molecule-1 pada Preeklamsia
}

\author{
Anita D. Anwar, ${ }^{1}$ Tri Hanggono Achmad, ${ }^{2}$ Hadyana Sukandar, ${ }^{3}$ Sofie R. Krisnadi, ${ }^{1}$ \\ Firman F. Wirakusumah ${ }^{1}$ \\ ${ }^{1}$ Bagian Obstetri dan Ginekologi, ${ }^{2}$ Bagian Biokimia, ${ }^{3}$ Bagian Epidemiologi \\ Fakultas Kedokteran Universitas Padjadjaran \\ Rumah Sakit Hasan Sadikin, Bandung
}

\begin{abstract}
Abstrak
Transforming growth factor- $\beta$ (TGF- $\beta$ ) diduga berperan pada preeklamsia. Reseptor TGF- $\beta$ tipe II (T $\beta$ R-II) dihasilkan dari transkripsi gen TGF- $\beta$ receptor type II (TGFBR2). Polimorfisme gen TGFBR2 pada basa C1167T dapat menyebabkan hipoksia yang menginduksi iskemia serta meningkatkan produksi solubel endoglin (sEng) dan vascular cell adhesion molecule-1 (VCAM-1). Tujuan penelitian ini untuk mengetahui korelasi polimorfisme gen $T G F B R 2$ pada basa $C 1167 T$ dengan kadar sEng dan VCAM-1 ibu preeklamsia. Subjek adalah ibu preeklamsia usia kehamilan 28-42 minggu dan kehamilan normal sebagai kontrol, masing-masing 120 orang. Penelitian dilakukan di Rumah Sakit Hasan Sadikin, Bandung, September 2008-Mei 2009. Sampel berupa darah vena, pemeriksaan polimorfisme dilakukan dengan DNA Wizard ${ }^{\circledR}$ genomic DNA purification, kadar sEng dan VCAM-1 dengan imunoesai. Hasil penelitian menunjukkan polimorfisme CT pada kelompok preeklamsia 92 (76,7\%) dan kontrol 70 $(58,3 \%)\{\mathrm{p}<0,001$; OR $(95 \% \mathrm{CI}): 2,35(1,30-4,26)\}$. Kadar sEng (ng/mL) 12,46 berbanding 10,29 pada kelompok kontrol $\{\mathrm{p}<0,001$; OR $(95 \% \mathrm{CI}): 3,71(2,11-6,57)\}$. Kadar VCAM-1 berbeda bermakna, yaitu 1.218,43 berbanding $705,59\{(\mathrm{p}<0,001 ;$ OR $(95 \% \mathrm{CI}): 7,56(4,11-14,0)\}$. Disimpulkan terdapat perbedaan proporsi dan korelasi polimorfisme $C 1167 T$ gen $T G F B R 2$, kadar sEng, dan VCAM-1 antara preeklamsia dan kehamilan normal.
\end{abstract}

[MKB. 2010;42(3):115-22].

Kata kunci: Polimorfisme gen TGFBR2, preeklamsia, sEng, VCAM-1

\section{C1167T Type II Transforming Growth Factor- $\beta$ Receptor Gene Polymorphism, Soluble Endoglin and Vascular Cell Adhesion Molecule-1 Levels in Preeclampsia}

\begin{abstract}
Transforming growth factor- $\beta$ (TGF- $\beta$ ) plays a role in preeclampsia. TGF- $\beta$ receptor type II (T $\beta$ R-II) is produced from the transcription of the type II TGF- $\beta$ receptor gene (TGFBR2). Polymorphism of TGFBR2 gene on the base $C 1167 T$ could cause hipoxia that induces ischaemia and product soluble endoglin (sEng) and vascular cell adhesion molecule-1 (VCAM-1). The aim was to find out the association of C1167T type II TGF- $\beta$ receptor gene polymorphism with sEng and VCAM-1 levels in preeclampsia. The study was done at Hasan Sadikin Hospital, Bandung, September 2008-May 2009. Indicates that C1167T polymorphism events were found in the preeclampsia that were $92(76.7 \%)$ of 120 cases and $70(58.3 \%)$ control of 120 normal pregnancies with the difference in the appearance polymorphism which means $\mathrm{p}<0.001 \mathrm{OR}(95 \% \mathrm{CI}): 2,35(1.30-4.26)$. There was a difference between sEng $(\mathrm{ng} / \mu \mathrm{L}) 12.46$ for preeclampsia and 10.29 for the control group $\mathrm{p}<0.001 \mathrm{OR}(95 \% \mathrm{CI}): 3.71(2.11-6.57)$. There was also a difference between VCAM-1 (ng/ $\mu \mathrm{L})$ 1,218.43 for the preeclampsia and 705.59 for the control group $\{\mathrm{p}<0.001$ OR $(95 \% \mathrm{CI}): 7.56(4.11-14.0)\}$. There was a result that in preeclamptic patient having polymorphism
\end{abstract}

Korespondensi: Dr. dr. Anita D. Anwar, Sp.OG(K). Bagian Obstetri dan Ginekologi Fakultas Kedokteran Universitas Padjadjaran, Rumah Sakit Hasan Sadikin. jalan Pasteur 38 Bandung 40161, mobile 0811225455,

e-mail: anitadebbya@yahoo.com. 
sEng level was $14.19 \mathrm{ng} / \mathrm{mL}$ and VCAM-1 level is $961,85 \mathrm{ng} / \mathrm{mL}$. It is concluded that there are difference proportion and association of C1167T type II TGF- $\beta$ receptor gene polymorphism with sEng and VCAM-1 levels between preeclampsia and normal pregnancy patients. [MKB. 2010;42(3):115-22].

Key words: Preeclampsia, sEng, TGFBR2 gene polymorphism, VCAM-1

\section{Pendahuluan}

Preeklamsia merupakan salah satu jenis hipertensi dalam kehamilan. Preeklamsia berkaitan dengan morbiditas serta mortalitas ibu dan janin, juga meningkatkan risiko penyakit kardiovaskular ibu di masa mendatang. Jalur molekuler mengatur proses vaskulogenesis yang melibatkan faktor angiogenik dan reseptornya. Proses angiogenesis membutuhkan faktor pro dan antiangiogenik yang bekerja sama dalam perkembangan plasenta. Dua macam protein antiangiogenik yang diproduksi berlebihan dan bertanggung jawab pada fenotip preeklamsia, yaitu soluble fms-like tyrosine kinase-1 (sFlt-1) dan soluble endoglin (sEng), sedangkan faktor proangiogenik adalah vascular endothelial growth factor (VEGF), placental growth factor (PlGF), dan transforming growth factor- $\beta$ (TGF- $\beta$ ).

Reseptor tipe II (TRR-II) yang dihasilkan dari transkripsi gen TGFBR2 memiliki peran penting sebagai pengikat ligan TGF- $\beta$ pada kompleks reseptor TGF- $\beta$. Kerusakan reseptor T $\beta$ R-II dapat mengakibatkan terhambatnya transduksi sinyal TGF- $\beta$ sehingga menganggu berbagai aktivitas sel. Perubahan susunan nukleotida gen tersebut dapat mempengaruhi kondisi dan ekspresi $T \beta R-I I$. Gen TGFBR2 C1167T yang mengalami polimorfisme menyebabkan tidak terjadinya ekspresi reseptor di permukaan sel, sehingga saat implantasi tidak muncul faktor vaskulogenesis dan vasokonstriksi.

Vasokonstriksi dapat menyebabkan kondisi hipoksia dan akan menyebabkan iskemia endotel vaskular plasenta serta merangsang pengeluaran protein antiangiogenik yang bersifat inhibisi terhadap sistem angiogenik. Salah satu protein antiangiogenik adalah sEng. Kejadian iskemia endotel vaskular ditandai dengan pelepasan vascular cell adhesion molecule-1 (VCAM-1).

\section{Metode}

Penelitian observasional analitik, disain kasus kontrol dilakukan pada ibu hamil pada saat memeriksakan kehamilan atau bersalin pada usia kehamilan 28-42 minggu di Rumah Sakit Hasan Sadikin (RSHS). Kelompok kasus adalah 120 pasien preeklamsia (hal ini sesuai protokol Divisi Fetomaternal Bagian Obstetri dan Ginekologi RSHS/FKUP tahun 2008) dengan kontrol sebanyak 120 kehamilan normal tanpa komplikasi obstetri/medis lain. Penelitian berlangsung dari September 2008 sampai Mei 2009. Pemilihan pasien preeklamsia dilakukan secara berurutan menurut kedatangan (consecutive admission) sesuai kriteria penerimaan, kelompok kontrol ditentukan secara matching. Pemeriksaan fisis meliputi keadaan umum, kesadaran, berat badan, tinggi badan, dan pemeriksaan jantung-paru. Tekanan darah sistolik dan diastolik diukur dengan sfigmomanometer merek Nova dan stetoskop Littman dalam posisi tidur miring ke kiri, setelah penderita diistirahatkan 15 menit. Hasil pengukuran yang diambil adalah rata-rata dari dua kali pengukuran dengan interval 5 menit.

Untuk pemeriksaan kadar sEng diambil 3,5 $\mathrm{mL}$ darah vena kubiti dengan vacutainer/tabung bebas pirogen, sedangkan untuk VCAM-1, antikoagulan ethylenediaminetetraacetic acid (EDTA) ditambahkan. Kadar sEng ditentukan secara duplikasi mempergunakan teknik ELISA dengan kit Human soluble endoglin immunoassay (Quantikine) sesuai pedoman produsen (R\&D System inc., Minnepolis, MN).

Pemeriksaan polimorfisme terdiri dari beberapa tahapan, isolasi DNA, polymerase chain reaction (PCR), dan sekuensing. Untuk isolasi DNA digunakan kit DNA Wizard ${ }^{\circledR}$ genomic DNA purification dari Promega, jaringan yang dipakai adalah darah lengkap $2 \mathrm{~mL}$ dengan EDTA. Isolasi fragmen TGFBR2 menggunakan primer Forward 5' CCT CCA CAG TGA TCA CAC TC 3' dan Reverse 5' TAA AGG GGA TCT AGC ACT AGC 3' sesuai dengan penelitian Lucke. Kit PCR yang digunakan adalah Go Taq Green Master MixPromega.

Polymerase chain reaction yang digunakan adalah: preheat pada suhu $95^{\circ} \mathrm{C}$ selama 3 menit, 
denaturasi pada suhu $95^{\circ} \mathrm{C}$ selama 30 detik, annealing pada suhu $55^{\circ} \mathrm{C}$ selama 1 menit, ekstensi pada suhu $72^{\circ} \mathrm{C}$ selama 1 menit, dan ekstraekstensi pada suhu $72^{\circ} \mathrm{C}$ selama 10 menit. Produk PCR yang dihasilkan berukuran $218 \mathrm{pb}$, dideteksi keberadaannya dengan elektroforesis dalam gel agarosa $2 \%$.

Analisis data dengan uji Hardy Weinberg, yaitu uji statistik untuk menilai keseimbangan proporsi alel dan genotip dari suatu kelompok; uji Chi square digunakan untuk membandingkan dua kelompok karakteristik subjek, frekuensi genotip, dan polimorfisme gen TGFBR2; uji MannWhitney untuk membandingkan perbedaan kadar protein plasma pada dua kelompok, sedangkan analisis regresi logistik berganda (multiple logistic regression) untuk mengendalikan variabel perancu. Program SPSS dipakai dengan derajat kepercayaan $95 \%$ dan nilai $\mathrm{p} \leq 0,05$.
Hasil

Karakteristik subjek penelitian meliputi usia, usia kehamilan, paritas, dan indeks massa tubuh (IMT) (Tabel 1). Karakteristik subjek antara kedua kelompok tidak berbeda bermakna.

Tabel 2 menunjukkan proporsi genotip 1167 gen TGFBR2 pada preeklamsia dan kehamilan normal berbeda bermakna.

Pada Tabel 3 tertera kejadian polimorfisme alel 1167 gen $T G F B R 2$ pada preeklamsia dan kehamilan normal secara statistik menunjukkan perbedaan yang bermakna.

Pada Tabel 4 terlihat perbandingan kadar sEng dan VCAM-1 antara kedua kelompok yang mengalami polimorfisme. Kadar sEng dan VCAM-1 pada kelompok preeklamsia lebih besar dibanding kehamilan normal. Analisis statistik menunjukkan perbedaan bermakna.

Tabel 1 Karakteristik Subjek Penelitian

\begin{tabular}{|c|c|c|c|}
\hline \multirow{2}{*}{ Variabel } & \multicolumn{2}{|c|}{ Kelompok } & \multirow{2}{*}{ Nilai $p$} \\
\hline & Preeklamsi $(n=120)$ & $\operatorname{Kontrol}(n=120)$ & \\
\hline Usia Kehamilan (minggu) & & & 0,678 \\
\hline $28-32$ & 40 & 37 & \\
\hline $33-37$ & 80 & 83 & \\
\hline $\bar{x}(\mathrm{SD})$ & $33,8(1,5)$ & $33,4(1,7)$ & \\
\hline Rentang & $32-36$ & $31-36$ & \\
\hline $\operatorname{IMT}\left(\mathrm{kg} / \mathrm{m}^{2}\right)$ & & & $\left.0,154^{*}\right)$ \\
\hline $\bar{x}(\mathrm{SD})$ & $23,3(1,8)$ & $23,1(1,5)$ & \\
\hline Rentang & $19-26$ & $19-26$ & \\
\hline Usia Ibu (tahun) & & & 0,061 \\
\hline$<20$ & 7 & 3 & \\
\hline $20-34$ & 64 & 81 & \\
\hline$>35$ & 49 & 36 & \\
\hline $\bar{x}(\mathrm{SD})$ & $31,4(7,0)$ & $34,1(5,4)$ & \\
\hline Rentang & $17-45$ & $17-45$ & \\
\hline Paritas & & & 0,584 \\
\hline $0-1$ & 42 & 44 & \\
\hline $2-3$ & 68 & 70 & \\
\hline$>4$ & 10 & 6 & \\
\hline
\end{tabular}

Tabel 2 Proporsi Genotip 1167 Gen TGFBR2 pada Penderita Preeklamsi dan Kehamilan Normal

\begin{tabular}{|c|c|c|c|}
\hline \multirow[b]{2}{*}{$\begin{array}{l}\text { Variabel } \\
\text { Genotip }\end{array}$} & \multicolumn{2}{|c|}{ Kelompok } & \multirow[b]{2}{*}{ OR $(95 \% C I)$} \\
\hline & $\begin{array}{c}\text { Preeklamsi } \\
(n=120)\end{array}$ & $\begin{array}{c}\text { Kehamilan Normal } \\
(n=120)\end{array}$ & \\
\hline $\mathrm{CC}$ & 28 & 50 & 1,0 \\
\hline $\mathrm{CT}$ & 84 & 58 & $2,59(1,41-4,77)$ \\
\hline TT & 8 & 12 & $1,19(0,39-3,62)$ \\
\hline
\end{tabular}


Anita D. Anwar: Polimorfisme C1167T Gen Reseptor Tipe II Transforming Growth Factor- $\beta$ pada Preeklamsia

Tabel 3 Kejadian Polimorfisme pada Penderita Preeklamsi dan Kehamilan Normal

\begin{tabular}{ccc}
\hline \multirow{2}{*}{ Polimorfisme } & \multicolumn{2}{c}{ Kelompok } \\
\cline { 2 - 3 } & Preeklamsi $(\mathbf{n}=\mathbf{1 2 0})$ & Kehamilan Normal $(\mathbf{n}=\mathbf{1 2 0})$ \\
\hline+ & 92 & 70 \\
- & 28 & 50 \\
\hline Keterangan: $\chi^{2}=9,193 ; \mathrm{p}=0,002 ;$ OR $(95 \% \mathrm{CI}): 2,35(1,30-4,26)$ &
\end{tabular}

Tabel 4 Perbandingan Kadar sEng dan VCAM-1 pada Kelompok Polimorfisme Positif antara Preeklamsi dan Kehamilan Normal

\begin{tabular}{|c|c|c|c|c|}
\hline \multirow[t]{2}{*}{ Variabel } & \multicolumn{2}{|r|}{ Kelompok } & \multirow[b]{2}{*}{$\mathbf{Z}_{\mathrm{M}-\mathrm{W}}$} & \multirow{2}{*}{ Nilai $p_{F}$} \\
\hline & Preeklamsi $(\mathrm{n}=92)$ & Kehamilan Normal $(n=70)$ & & \\
\hline Kadar sEng (ng/mL) & & & 3,510 & $<0,001$ \\
\hline Rata-rata & 12,46 & 10,29 & & \\
\hline Median & 14,19 & $9-22$ & & \\
\hline Rentang & $4,49-16,78$ & $4,94-16,3$ & & \\
\hline Kadar VCAM-1 (ng/ mL) & & & 7,354 & $<0,001$ \\
\hline Rata-rata & $1.218,43$ & 705,59 & & \\
\hline Median & 961,85 & 578,3 & & \\
\hline Rentang & $477,7-3.633,4$ & $323,9-1.322,2$ & & \\
\hline
\end{tabular}

Keterangan: OR (95\%CI) sEng: 3,71 (2,11-6.57); VCAM-1: 7,56 (4,11-14,0)

Tabel 5 Hubungan Polimorfisme, Kadar Seng, VCAM-1, dan Faktor Perancu dengan Kejadian Preeklamsi berdasarkan Analisis Regresi Logistik Ganda

\begin{tabular}{|c|c|c|c|c|}
\hline Variabel & Koefisien B & SE(B) & Nilai p & OR (95\%CI) \\
\hline Usia & 0,331 & 0,164 & 0,044 & $1,39(1,01-1,92)$ \\
\hline sEng & 0,717 & 0,330 & 0,030 & $2,05(1,07-3,91)$ \\
\hline VCAM-1 & 1,742 & 0,328 & $<0,001$ & $5,71(3,00-10,87)$ \\
\hline Polimorfisme (-/+) & 1,050 & 0,335 & 0,002 & $2,86(1,48-5,52)$ \\
\hline Konstanta & $-2,525$ & - & - & \\
\hline
\end{tabular}

Keterangan: Akurasi model=75\%; Usia: 1. 20-34; 2. $<20 ; 3$. $\geq 35$; sEng: 0: $<11,8 ; 1: \geq 11,8 ;$ VCAM-1: 0: $<769,4 ; 1: \geq 769,4$; Polimorfisme: $0=$ negatif; $1=$ positif

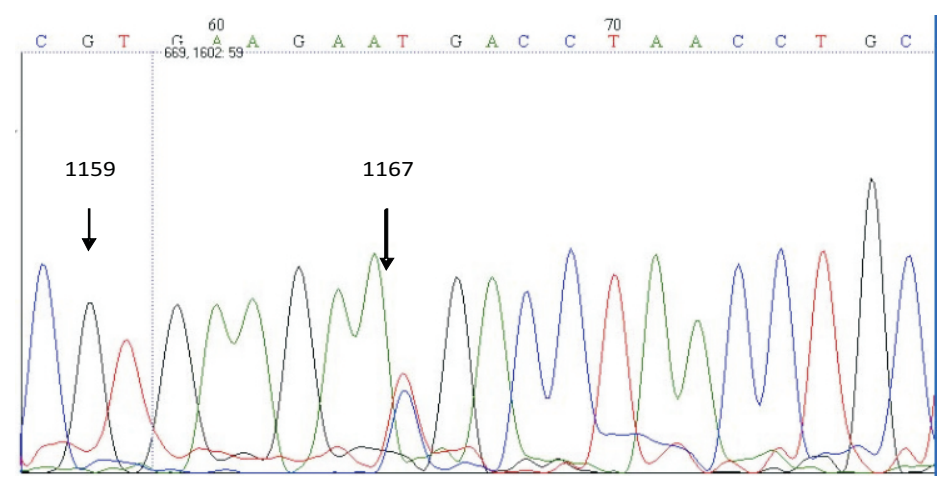

Gambar Elektroforegram Hasil Sekuensing (Genotip CT)

\section{Pembahasan}

Tabel 1 menunjukkan pada kedua kelompok tidak didapatkan perbedaan karakteristik bermakna sehingga hasil pemeriksaan selanjutnya layak diperbandingkan. Usia ibu merupakan salah satu faktor risiko preeklamsia, risiko tertinggi pada usia di bawah 20 tahun dan di atas 35 tahun. Jumlah kasus yang mengalami preeklamsia berusia $<20$ tahun lebih besar dibandingkan 
dengan jumlah kontrol pada usia yang sama, begitu pula perbedaan jumlah individu yang berusia di atas 35 tahun. Jumlah kasus yang mengalami preeklamsia berusia di atas 35 tahun lebih tinggi dibandingkan dengan kontrol pada usia yang sama, tetapi pada kelompok usia 20-34 (produktif) berbeda. Jumlah individu preeklamsia pada kelompok usia 20-34 lebih rendah dibandingkan dengan kontrol pada usia yang sama. Hal ini menunjukkan bahwa pada usia produktif, risiko preeklamsia lebih rendah dibandingkan dengan usia di bawah 20 tahun dan di atas 35 tahun.

Usia kehamilan berpengaruh pada preeklamsi yang muncul pada kehamilan 28 minggu seperti pada penelitian ini yaitu pada kehamilan 28-37 minggu. Usia kehamilan tidak merupakan faktor risiko preeklamsia, tetapi berpengaruh pada derajat beratnya preeklamsia. Semakin tua usia kehamilan, risiko berlanjut menjadi preeklamsia berat semakin tinggi. Indeks massa tubuh (IMT) yang tinggi merupakan salah satu faktor risiko hipertensi yang juga berpengaruh pada preeklamsia. Peningkatan IMT pada ibu hamil akan menambah risiko terjadinya preeklamsia. Sibai et $a .^{8}$ melaporkan wanita dengan IMT kurang dari 19,8 mempunyai risiko preeklamsia sebesar 4,3\%, sedangkan IMT lebih dari 35 risikonya 3 kali lipat, yaitu sekitar $13,3 \%$. Wanita overweight berisiko mengalami preeklamsia 2 kali lipat (95\%IK: 1,365-2,983) dan obesitas berisiko 3,2 kali lipat (95\%IK: 1,7-5,909) untuk mengalami preeklamsia dibanding wanita dengan berat badan normal.

Paritas merupakan faktor risiko preeklamsia lainnya. Penelitian lain menunjukkan frekuensi preeklamsia terjadi lebih tinggi pada primigravida daripada multigravida, tetapi pada Tabel 1 diperlihatkan kondisi berbeda. Pada penelitian ini, jumlah kasus preeklamsia pada pasien dengan paritas 2-3 lebih tinggi dibandingkan dengan paritas $0-1$. Hal tersebut mungkin terjadi karena faktor lain yang mempengaruhi preeklamsia, seperti usia ibu, usia kehamilan, IMT, dan riwayat penyakit lainnya yang menyertai, seperti gagal ginjal kronik, diabetes melitus, dan hipertensi.

Produk PCR sesudah itu diperiksa urutan basanya menggunakan metode direct sequencing oleh Macrogen, Inc., Korea Selatan. Metode sekuensing dipilih karena tidak adanya motif basa yang dapat dipotong oleh enzim restriksi di area sekitar target. Hasil sekuensing didapatkan dalam beberapa format, salah satunya adalah format elektroforegram. Pada elektroforegram terdapat beberapa kurva dengan empat warna berbeda. Warna biru menunjukkan basa sitosin (C), warna hitam basa guanin $(\mathrm{G})$, warna hijau basa adenin (A), dan warna merah basa timin (T), (Gambar 1) Pembacaan elektroforegram didasarkan pada warna kurva yang membentuk puncak tertinggi. Jika terdapat satu puncak kurva, diasumsikan bahwa pada posisi tersebut terdapat pasangan alel homozigot, jika terdapat dua puncak kurva yang memiliki tinggi relatif sama, maka pada posisi tersebut diasumsikan pasangan alel heterozigot.

Metode homologi dilakukan pada urutan basa yang terdapat pada produk PCR dengan basa gen TGFBR2 baku dalam Gene Bank (Accession number: M85079.1). Metode homologi dilakukan dengan menggunakan piranti lunak ClustalW2 yang diakses secara online pada http://www.ebi. ac.uk.

Dari hasil homologi dapat ditentukan basa target $(\mathrm{C} 1167 \mathrm{~T})$. Hasil homologi tersebut hanya menunjukkan basa pada salah satu alel saja. Penentuan pasangan basanya ditentukan dengan cara pembacaan visual terhadap elektroforegram hasil sekuensing. Tabel 2 menunjukkan bahwa pada kelompok preeklamsia muncul ketiga tipe genotip yaitu CC, CT, dan TT. Genotip yang paling banyak ditemukan adalah genotip CT yang bersifat heterozigot, sedangkan genotip CC dan TT yang bersifat homozigot berjumlah lebih sedikit. Pada kelompok kehamilan normal juga didapatkan ketiga genotip dan $\mathrm{CT}$ merupakan genotip yang terbanyak. Pada kedua kelompok proporsi genotip berbeda bermakna, keadaan ini menunjukkan bahwa preeklamsia berhubungan dengan tipe genotip.

Penelitian Yoshida ${ }^{9}$ juga menemukan ketiga tipe genotip (CC, CT, dan TT) 1167 gen TGFBR2 pada chronic kydney disease (CKD). Munculnya ketiga tipe genotip pada kedua kelompok (CKD dan kontrol) sama dengan hasil yang didapatkan pada penelitian ini, hal ini menunjukkan bahwa polimorfisme $C 1167 T$ bukan merupakan faktor utama ataupun faktor tunggal dalam patogenesis penyakit CKD maupun preeklamsia.

Tabel 3 menunjukkan kejadian polimorfisme basa 1167 gen TGFBR2 pada preeklamsia dan kehamilan normal. Polimorfisme terdapat pada kedua kelompok tersebut, tetapi berbeda pada frekuensinya. Frekuensi polimorfisme pada preeklamsia lebih tinggi dibandingkan dengan 
kehamilan normal. Hal ini menunjukkan adanya hubungan polimorfisme dengan preeklamsia. Odds Ratio memperlihatkan bahwa individu dengan polimorfisme meningkatkan risiko preeklamsia sebesar 2,35 kali lebih tinggi dibanding yang tidak memiliki polimorfisme.

Lucke et al. ${ }^{10}$ meneliti polimorfisme gen TGFBR2 basa C1167T pada penyakit kanker payudara, di antara beberapa SNP yang dianalisis, ternyata basa ke C1167T tidak memiliki hubungan dengan rekurensi kanker payudara. Polimorfisme didapat pada sampel DNA tumor dan DNA normal. Tabel 2 memperlihatkan hasil yang sama dengan asumsi penelitian tersebut. Hasil menunjukkan bahwa polimorfisme gen TGFBR2 pada basa $C 1167 T$ tidak hanya terjadi pada preeklamsia, tetapi juga pada kelompok kontrol yang memiliki tekanan darah normal. Penelitian Lucke et al. tidak membahas fenomena tersebut, namun diduga karena tipe mutasi $C 1167 T$.

Tipe mutasi yang terjadi pada gen TGFBR2 C1167T merupakan silent mutation yang tidak menyebabkan perubahan susunan asam amino. Protein T $\beta$ R-II pada individu yang mengalami polimorfisme masih berfungsi normal dan mempunyai pengaruh yang sama dengan individu tanpa polimorfisme. Hal tersebut menjelaskan adanya polimorfisme pada kelompok normal dan nonpolimorfisme pada kelompok preeklamsia, yang menunjukkan polimorfisme gen TGFBR2 tersebut tidak berhubungan dengan preeklamsia. Hasil berbeda ditemukan pada penelitian Yoshida et al. ${ }^{9}$ menunjukkan polimorfisme gen TGFBR2 basa $C 1167 T$ terbukti berkaitan dengan CKD. Hal tersebut berarti terdapat peran polimorfisme ini terhadap kejadian CKD, meskipun mekanisme biomolekulernya belum dapat dijelaskan dengan pasti.

Penelitian Plotkin ${ }^{11}$ dinyatakan bahwa silent mutation dapat mempengaruhi ekspresi protein yang dikodenya. Salah satu bentuk pengaruhnya adalah mengubah tingkat ekspresi suatu protein. Beberapa peneliti menemukan bahwa gen yang tidak efisien akan memproduksi molekul mRNA dengan lipatan yang erat sehingga tidak dapat diakses oleh mesin pembuat protein. Berdasarkan hal tersebut lipatan mRNA dan tingkat inisiasi translasi terkait bersifat predominan dalam membentuk kadar ekspresi gen individual yang bias kodonnya dapat mempengaruhi efisiensi translasi global dan kemampuan selular. Hal tersebut juga dikemukakan oleh Pearson ${ }^{12}$ yang menyatakan bahwa pada protein yang memiliki setidaknya satu silent mutation, bentuknya sedikit berbeda dibanding protein normal. Dua tipe silent mutation pada penelitian Kimchi-Sarfaty ${ }^{13}$ menggantikan kodon umum dengan kodon yang jarang terjadi. Hal tersebut menyebabkan proses translasi tidak secepat translasi kodon umum. Penyelaan pada saat produksi protein tersebut dapat menyebabkan lipatan protein menjadi sedikit berbeda. Silent mutation juga diketahui memiliki efek lainnya, salah satunya adalah dapat mengubah proses cut dan splicing RNA.

Penelitian memperlihatkan kemungkinan mutasi gen TGFBR 2 juga mempengaruhi tingkat ekspresi protein T $\beta R$-II sehingga ekspresi protein T $\beta R$-II di permukaan sel menjadi rendah. Penurunan kadar protein T $\beta$ R-II di permukaan sel tersebut akan menurunkan aktivitas sinyal TGF- $\beta$ yang dibutuhkan dalam proses remodeling dan angiogenesis, dengan demikian menyebabkan preeklamsia. Hal tersebut mendukung dugaan polimorfisme gen TGFBR2 pada basa C1167T berhubungan dengan preeklamsia. Polimorfisme pada gen TGFBR2 dapat menyebabkan penurunan tingkat ekspresi T $\beta$ R-II, sehingga kerja TGF- $\beta$ menurun. Keadaan tersebut akan menyebabkan transduksi sinyal TGF- $\beta$ terhambat sehingga beberapa proses transkripsi gen yang diregulasi sinyal TGF- $\beta 1$ tidak dapat terjadi. Gen tersebut mampu mengekspresikan beberapa faktor yang dapat menghambat terjadinya vasokonstriksi. Mekanisme molekuler penurunan kadar T $\beta$ R-II yang disebabkan oleh polimorfisme C1167T hingga kini belum dapat diungkapkan dengan pasti. Beberapa teori dasar dapat digunakan sebagai asumsi mekanisme molekuler yang mungkin terjadi. Alel $\mathrm{T}$ yang terdapat pada individu polimorfisme dapat mengubah struktur lipatan mRNA yang berbeda dibanding mRNA yang dikode dari gen yang memiliki alel $\mathrm{C}$. Perbedaan terjadi pada bentuk lipatan mRNA. Perbedaan lipatan tersebut disebabkan oleh perbedaan basa yang memiliki kekuatan interaksi yang berbeda dengan basa lainnya, sehingga struktur lipatan yang terbentuk pun akan berbeda. Perbedaan lipatan tersebut akan mempengaruhi ikatan mRNA dengan ribosom dan berpengaruh dalam proses menerjemahkan kode mRNA. Asam amino yang dihasilkan memang tidak berbeda, akan tetapi ribosom akan menerjemahkan mRNA alel T terutama pada kodon 389 lebih lama karena bentuk lipatannya sebelum ribosom melanjutkan 
proses translasi. Pada translasi mRNA alel $\mathrm{T}$ mungkin terjadi penyelaan sehingga protein T $\beta \mathrm{R}$ II yang dihasilkan memiliki struktur berbeda dari struktur normal mengakibatkan protein tersebut tidak berfungsi sehingga tidak terekspresikan pada membran sel, menyebabkan berkurangnya kadar T $\beta$ R-II. Kodon 389 merupakan area penyusun domain serin/treonin kinase yang berperan dalam transduksi sinyal hasil dari ikatannya dengan ligan ke reseptor sitoplasma. Pada kondisi normal, domain tersebut akan mengalami perubahan apabila terjadi ikatan dengan ligan. Perubahan tersebut menyebabkan T $\beta R$-I mendekat dan membentuk kompleks. Apabila perubahan yang disebabkan C1167T di domain serin/treonin kinase pada T $\beta \mathrm{R}$-II menyerupai struktur domain aktif, maka terjadi mekanisme sinyaling terhadap sel meskipun tidak ada ligan dan dapat mengakibatkan sinyaling berlebih yang mempengaruhi ekspresi gen lainnya.

Faktor antiangiogenik merupakan salah satu faktor risiko terjadinya preeklamsia, di antaranya adalah sEng. Hasil penelitian Levine et al. ${ }^{14}$ dinyatakan bahwa kadar sEng pada preeklamsia dua kali lebih tinggi dibandingkan sEng pada kehamilan normal. Hal tersebut sesuai dengan hasil penelitian ini, yaitu didapat perbedaan antara kadar sEng pada preeklamsia dan kontrol. Pada hasil penelitian terlihat dengan jelas perbedaan bermakna antara kadar sEng pada preeklamsia dan kontrol. Kadar sEng pada preeklamsia lebih tinggi dibandingkan dengan populasi kontrol. Hal ini menunjukkan pengaruh preeklamsia terhadap kadar sEng yang dapat dipengaruhi oleh beberapa faktor. Salah satu penelitian membuktikan pada plasenta preeklamsia tidak terdapat faktor proteksi endogen seperti heme-oxygenase-1, dismutase antioksida, superoksida, dan glutation peroksi-dase, sehingga sEng meningkat. Kondisi hipoksia yang terjadi pada populasi preeklamsia juga dapat memicu terjadinya peningkatan sEng. ${ }^{15}$

Levine et al. $^{16}$ menyatakan kadar VCAM-1 pada wanita preeklamsi lebih tinggi dibandingkan dengan wanita normal. Kim et al. ${ }^{17}$ menyatakan bahwa VCAM-1 merupakan indikasi terdapatnya inflamasi pada preeklamsia. Inflamasi itu sendiri disebabkan oleh kerusakan endotel, sehingga VCAM-1 dapat dijadikan penanda adanya kerusakan endotel. Peningkatan VCAM-1 menunjukkan kemungkinan adanya perubahan aktivitas sel endotel, dengan demikian terdapat kemungkinan adanya kerusakan endotel pada preeklamsia. Hasil tersebut sesuai dengan penelitian Hanisch et $a l^{18}$ yang menyatakan bahwa peningkatan kadar VCAM-1 terjadi pada preeklamsia dibandingkan dengan kehamilan normal. Peningkatan VCAM-1 menunjukkan adanya aktivasi sel endotel.

Pada Tabel 4 tertera hasil perbandingan kadar sEng dan VCAM-1 pada kelompok polimorfisme positif antara preeklamsia dan kehamilan normal. Data menunjukkan bahwa polimorfisme tidak mempengaruhi perubahan kadar sEng dan VCAM-1. Gen yang dipengaruhi oleh keberadaan transduksi sinyal TGF- $\beta 1$ salah satunya adalah gen plasminogen activator inhibitor-1 (PAI-1). Tidak terekspresinya gen tersebut menyebabkan kadar PAI-1 menjadi rendah, yang akan mengakibatkan fibrosis pada sel endotel sehingga terjadi vasokonstriksi. Vasokonstriksi yang terjadi dapat memicu produksi VCAM-1, sehingga dapat disimpulkan bahwa polimorfisme pada gen TGFBR2 akan menekan kadar PAI-1 yang menyebabkan vasokonstriksi dan menginduksi peningkatan VCAM-1. Berdasarkan pembahasan di atas maka dapat diasumsikan bahwa terdapat hubungan antara polimorfisme, sEng, dan VCAM-1 dengan preeklamsia. Dilakukan analisis regresi logistik berganda untuk menilai hubungan polimorfisme, kadar sEng, VCAM-1, dan faktor perancu dengan kejadian preeklamsia (Tabel 5). Faktor perancu yang digunakan adalah faktor usia ibu yang sangat berpengaruh terhadap kejadian preeklamsia dibanding faktor perancu lainnya. Hasil analisis menunjukkan faktor yang paling berpengaruh terhadap preeklamsia adalah VCAM-1. Polimorfisme merupakan faktor yang paling berhubungan dengan preeklamsia setelah VCAM-1. Kondisi ini terjadi dikarenakan polimorfisme berperan sebagai faktor risiko preeklamsia, sedangkan VCAM-1 merupakan penanda adanya preeklamsia. Keberadaan polimorfisme belum tentu mengakibatkan preeklamsia akan tetapi preeklamsia pasti melibatkan VCAM-1. Kondisi tersebut menyebabkan VCAM-1 lebih erat hubungannya dibandingkan polimorfisme. Kadar VCAM-1 $\geq 769,4 \mathrm{ng} / \mathrm{mL}$ meningkatkan 5,71 kali risiko preeklamsia. Polimorfisme $C 1167 T$ gen reseptor tipe II TGF- $\beta$ meningkatkan 2,86 kali risiko preeklamsia. Individu berusia $\geq 35$ tahun dan $<20$ tahun dengan kadar sEng $\geq 11,8 \mathrm{ng} / \mathrm{mL}$, kadar VCAM-1 $\geq 769,4 \mathrm{ng} / \mathrm{mL}$, dan polimorfisme positif memiliki peluang mengalami preeklamsia 
berturut-turut sebesar 0,8786 dan 0,8386 .

Disimpulkan terdapat perbedaan proporsi polimorfisme $C 1167 T$ gen reseptor tipe II TGF- $\beta$ antara preeklamsia dan kehamilan normal. Terdapat perbedaan kadar sEng dan kadar VCAM-1 preeklamsia dengan kehamilan normal. Terdapat hubungan polimorfisme C1167T gen reseptor tipe II TGF- $\beta$ dengan kadar sEng dan kadar VCAM-1 pada preeklamsia.

\section{Daftar Pustaka}

1. Duley L, Meher S, Abalos E. Management of preeclampsia. BMJ. 2006;332:463-8.

2. Lim JH, Kim SY, Park SY, Yang HH, Kim MY, Ryu HM. Effective prediction of preeclampsia by a combined ratio of angiogenesis -related factors. Obstet Gynecol. 2008;111(6):1403-9.

3. Maynard SE, Min JY, Merchan J, Lim KH, Mondal S, Libermann TA, et al. Excess placental soluble fms-like tyrosine kinase 1 (sFlt1) may contribute to endothelial dysfunction, hypertension, and proteinuria in preeclampsia. J Clin Invest. 2003;111:649-58.

4. Bdolah Y, Sukhatme VP, Karumanchi SA. Angiogenic imbalance in the pathophysiology of preeclampsia: newer insights. Semin Nephrol. 2004;24:548-56.

5. Loeys BL, Schwarze U, Holm T, Callewaert BL, Thomas GH, Pannu H. Aneurysm syndromes caused by mutations in the TGF-beta receptor. $\mathrm{N}$ Engl J Med. 2006;355:788-98.

6. Arrington C, Sower C, Chuckwuk N, Stevens J, Leppert M, Yetman A, et al. Absence of TGFBR1 and TGFBR2 mutations in patients with bicuspid aortic valve and aortic dilation. Am J Cardiol. 2009;102(5):629-31.

7. Jin G, Wang L, Chen W, Hu Z. Variant alleles of TGFB1 and TGFBR2 are associated with decreased risk of gastric cancer in a Chinese population. Epidemiology. 2006;120(6):1330-5.
8. Sibai B, Dekker G, Kupferminc M. Preeclampsia. Lancet. 2005;365:785-99.

9. Yoshida T, Kato K, Yokoi K, Oguri M, Watanabe $\mathrm{S}$, Metoki $\mathrm{N}$, et al. Association of gene polymorphism with chronic kidney disesase in high-or low-risk subjects defined by conventional risk factors. Int J Mol Med. 2009.

10. Lucke CD, Phillpott A, Metcalfe JC, Thompson AM, Hughes-Davies L, Kemp PR, et al. Inhibiting mutations in the transforming growth factor beta type 2 receptor in recurrent human breast cancer. Cancer Research. 2001;61:482-5.

11. Plotkin J. How 'silent' mutations influence protein production. Biology \& Nature. 2009.

12. Pearson H. Silent mutations speak up. Nature. 2006;DOI 10.1038.

13. Kimchy-Sarfaty C, Sauna ZE, Ambudkar SV, Gottesman MM. Silent polymorphisms speak: how they affect pharmacogenomics and the treatment of cancer. Cancer Res. 2007;67(20): 9609-12.

14. Levine RJ, Lam C, Qian C, Yu KF, Maynard SE, Sachs BP. Soluble endoglin and other circulating factors in preeclampsia. N Engl J Med. 2006;355: 992-1005.

15. Gu Y, Lewis DF, Wang Y. Placental productions and expressions of soluble endoglin, soluble fmslike tyrosine kinase receptor-1, and placental growth factor in normal and preeclamptic pregnancies. J Clin Endocrinol Metab. 2008;93:260-6.

16. Levine RJ, Maynard SE, Qian C, Lim KH, England LJ, Yu KF, et al. Circulating angiogenic factors and the risk of preeclampsia. N Engl J Med. 2004;350:672-83.

17. Kim SY, Ryu HM, Yang JH, Kim MY, Ahn HK, Woo HJ, et al. Maternal serum levels of VCAM-1, ICAM-1 dan E-selectin in preeclampsia. J Korean Med Sci. 2004;19:688-92.

18. Hanisch CG, Pfeiffer KA, Schlebusch H, Schmolling J. Adhesion molecules, activin and inhibin-candidates for the biochemical prediction of hypertensive disease in pregnancy? Arch Gynecol Obstet. 2004;270:110-5. 